\title{
EFFECT OF DIFFERENT METHODS OF VITAL TOOTH BLEACHING ON THE RESISTANCE OF ENAMEL TO EROSION USING ENERGY- DISPERSIVE X-RAY SPECTROMETRY ANALYSIS
}

\author{
Reham Mohammed Attia*, Eman Mohamed Sobhy Elbahrawy ** \\ and Mona Elsaied Abd El Hamed Essa***
}

\begin{abstract}
Objectives: the objective of the current study was to determine the effect of different methods of vital tooth bleaching (power in- office, at-home and over the counter) on the resistance of enamel to erosion. Material and methods: Square enamel sections $(4 \mathrm{~mm} \times 4 \mathrm{~mm} \times 3 \mathrm{~mm}$ ) were obtained from the middle third of the crown of bovine teeth and then embedded in self-curing acrylic resin blocks measuring ( $2 \mathrm{~cm}$ wide and $3 \mathrm{~cm}$ high). The samples were divided randomly into 4 groups according to the method of bleaching used. Group 1(control group): where all specimens of the group were placed in artificial saliva at $37^{\circ} \mathrm{C}$ during the study period. Group 2 (power in- office bleaching): The gel was applied directly on the enamel surface of the specimens where the thickness of the gel was about 1-2 mm, then the LED bleaching device was used. The lamp was located close to enamel surface, then it was turned on for 15 minutes for total application time 45 minutes. Group 3 (Crest 3D White Luxe Supreme FlexFit White strips (over the counter) : the strips were applied to the enamel surface for 30 min twice daily for 14 days according to manufacturer instructions. Group 4 (At-home bleaching): bleaching gel was applied to the enamel surface. Teeth were placed for 6 hours at $37^{\circ} \mathrm{C}$ daily for 8 days. Then, all the samples were subjected to erosive challenge where the bleached samples and the samples of control group were immersed in $1 \%$ citric acid solution. Mineral analysis via EDS was carried out before bleaching (base line), then of bleached enamel and finally after erosive cycle. Two representative samples of each group after each step were examined by scanning electron microscope. Results: There was a significant difference regarding the percentage weight of $(\mathrm{Ca} \%),(\mathrm{P} \%)$ and $(\mathrm{Ca} / \mathrm{P} \%)$ among the four tested groups. The difference was not significant between group 1 and group 4 after erosion. Conclusions: 1-At-home beaching is considered the least harmful to enamel compared to power in- office and over the counter bleaching materials, and it is more resistant to erosive challenges. 2- Bleaching agents containing calcium decrease the adverse effects of the bleaching procedure. 3-Bleached enamel is less resistant to erosion especially when power in -office or over the counter protocol is used.
\end{abstract}

Key words: Vital tooth bleaching, Erosion, Energy-Dispersive X-Ray Spectrometry.

\footnotetext{
* Lecturer of Operative Dentistry, Department of Conservative Dentistry, Faculty of Dentistry, Zagazig University, Zagazig, Egypt. ** Lecturer of Dental Biomaterials, Faculty of Dentistry, Tanta University, Egypt.

***Associate Professor of Operative Dentistry, Faculty of Dentistry, Beni-Suef University, Egypt.
} 


\section{INTRODUCTION}

Aesthetics is very important to patients where many individuals are more concerned about the aesthetic and attractive look of the smile ${ }^{(1)}$. This led to noticeable clinician's attentiveness of more conservative and less-invasive treatments and improvements of the modalities related to aesthetics (2). The colour of the tooth is determined by a combination of the intrinsic colour and the extrinsic stains that may be composed on the surface of the tooth ${ }^{(3)}$. Intrinsic colour of the tooth depends upon the dissemination of light and adsorption properties of the enamel and dentine of the tooth, with the properties of dentine playing the most important role in formation of the general tooth colour ${ }^{(4)}$. Extrinsic stains of the tooth may possibly be a consequence of inappropriate maintenance of cleaning of the teeth and ignoring the oral hygiene ${ }^{(5)}$. In addition; it may be increased with smoking, food intake of tanninrich foods (e.g. red wine) or some beverages that cause discoloration of the tooth.

The use of definite cationic agents as chlorhexidine, or metal salts such as tin and iron can cause discoloration ${ }^{(6)}$. The colour of the teeth may be enhanced by the use of different modalities as polishing of the teeth with polishing paste to eliminate the external tooth stains, scaling, macro-abrasions, micro-abrasions of enamel, bleaching, and finally crowns and veneers may be used ${ }^{(7)}$. Tooth bleaching is considered the easiest and most cost effective procedure for treating discoloration and it is one of the most common, safe and conservative approaches for management of tooth discoloration ${ }^{(1)}$.

At the commencement, tooth bleaching was limited to non-vital discoloured teeth, where bleaching was done using in-office techniques based on the application of hydrogen peroxide and sodium perborate, with or without heat ${ }^{(8)}$. Vital tooth bleaching started to be used as a teeth whitening method in 1989, as Heymann and Heywood recommended the so-called night-guard vital tooth bleaching ${ }^{(9)}$.
Bleaching is a decolourisation or whitening process that can take place in solution or on a surface. The colour producing materials are organic compounds that have extensive conjugated chains of alternating and irregular double or single bonds and frequently comprise hetero atoms, carbonyl, and phenyl rings in the conjugated system and are usually known as a chromophore ${ }^{(10)}$. Breakdown of the chromophore occurs via destruction of one or more of the double bonds in the chain, hydrogen peroxide oxidises a lot of organic and inorganic compounds ${ }^{(11)}$.

In general, the mechanism of the whitening effect of hydrogen peroxide is not very clear and it may depend upon creation of an active oxygen dependent on reaction conditions, such as $\mathrm{pH}$, light, temperature, and existence of transition metals (12). Under alkaline conditions, hydrogen peroxide usually expresses by the per-hydroxyl anion (HO2). It is able under another condition to decompose to free radical formation, for example, by homolytic cleavage of either an $\mathrm{O}-\mathrm{H}$ bond or the $\mathrm{O}-\mathrm{O}$ bond in hydrogen peroxide to give $\mathrm{H}_{-}+{ }_{-} \mathrm{OOH}$ and 2_OH (hydroxyl radical). In case of photo-chemically initiated reactions whether via utilizing lasers or light, the presence of hydroxyl radicals from hydrogen peroxide was found to raise ${ }^{(13)}$. After that, initial transmission of peroxide into and through the enamel occurs to reach the enamel dentine junction and dentine. When peroxide passes into the tooth structure, it is capable of reacting with coloured organic materials present within the tooth structures which leads to a diminution in colour ${ }^{(11)}$.

In - office and at-home tooth bleaching are considered the main and popular professional techniques ${ }^{(8,13)}$. In relation to at-home bleaching; the patients use custom-made tray filled and packed with bleaching material. The bleaching material in use is usually carbamide peroxide (CP) with a concentration of 5-35\% ${ }^{(14)}$. At-home bleaching using carbamide peroxide is the recommended bleaching 
method mostly due to its long-term successful results ${ }^{(15)}$. On the other hand, some patients do not feel comfortable during the manufacturing of a custom-made tray and have some anxiety concerning the time to fabricate the tray ${ }^{(16)}$. Others do not like the technique of bleaching, since they require to use the bleaching tray with bleaching material for longer periods of time ${ }^{(17)}$.

In-office bleaching usually uses somewhat high levels of bleaching agents, for example 15-40\% hydrogen peroxide containing products, for shorter time periods ${ }^{(18)}$. The soft tissue protection previous to bleaching agent application should be used. Activation of peroxide by heat or light may be done to increase the bleaching efficiency. Considerable whitening can be obtained after only one treatment appointment. However, many treatment visits for best possible whitening effect may be necessary ${ }^{(8)}$.

The advertising of over the counter (OTC) whitening products for at-home tooth bleaching resulted as a consequence of the attention obtained via bleaching systems with trays associated with the patients desires and requirements ${ }^{(19)}$. OTC bleaching products appeared in the USA in the beginning of the 2000s, as an alternative to management of tooth discoloration with less significant cost than methods practiced-prescribed/guided products which were performed under the supervision of a dentist ${ }^{(20)}$. The spread of these OTC products of whitening in the USA was in a definite way motivated by the Food and Drug Administration (FDA) ${ }^{(19)}$. In accordance with the FDA, OTC products might reduce injustice in the access to the health system, decreasing the cost of treatments ${ }^{(21)}$. Currently, many products like gels, rinses, paint-on product formats, dentifrices, gums, and whitening strips with low percentage of carbamide or hydrogen peroxide are largely available in the market ${ }^{(22)}$.

The whitening strips are one of the hydrogencontaining OTC whitening products. Whitening strips were produced with a view to exclude utilizing trays (23). Adhesive whitening strips containing bleaching agents are bonded to the labial surface of the anterior teeth, and they liberate the active component during a reasonably short time which may range from 5 to 60 minutes. It is suggested to be used once or twice per day. The active component is hydrogen peroxide (HP) in somewhat less concentrations (5 to 14\%). It is possible that the whitening effect of the OTC whitening strips may remain for a period extended to 2 years ${ }^{(24)}$. Because of the simple way of use, somewhat little cost and relatively fine aesthetic outcomes, the utilization of whitening strips has become an ever more accepted option of treatment ${ }^{(25)}$. As bleaching of discoloured teeth is considered one of the most common dental practices, it was necessary to study the biologic adverse effects of hydrogen peroxide (26). When it is used appropriately, peroxide-based whitening agent becomes effective and biologically safe. The most frequent side effects are gingival irritation and tooth sensitivity. These side effects are generally mild to moderate and temporary ${ }^{(27)}$. The effect of bleaching procedure and products on the tooth hard tissues are controversial. Some researchers showed that there was no adverse effects on the mechanical properties of hard tissues after bleaching procedure ${ }^{(28-31)}$, whereas other studies showed that different concentrations of bleaching material decreased enamel micro-hardness and increased surface roughness post-bleaching (32-35). Micro-hardness and surface roughness indirectly reflect the loss of minerals as a result of bleaching. Detection of mineral level in enamel can be measured using energy-dispersive X-ray spectrometry (EDS, EDX, EDXS or XEDS) which is an analytical technique used for the elemental analysis or chemical characterization of a sample. It relies on an interaction of some source of X-ray excitation with a sample ${ }^{(36) .}$

Dental erosion is defined as loss of the tooth tissue irreversibly by endogenous or exogenous acids with no bacterial participation associated with 
a progressive softening of the superficial and nearsurface layer of enamel ${ }^{(37),(38)}$. The enamel surface is affected by erosive challenges, which result from the action of acidic substances found in drinks and food available for individuals consumption ${ }^{(39)}$.

The dentists must recognize accurately all the information concerning the bleaching products, either for in- office professional use or for self-application by the patient, and have to be capable to advise their patients adequately. Even though the enamel changes resulted from erosion by acid solutions and effect of bleaching procedure on enamel surface have been usually investigated, few studies have analyzed the effect of erosion on tooth surfaces that have been bleached. In addition, there are many changes that may occur on the enamel surface after bleaching and decrease its resistance to intraoral challenges like erosion. So, the objective of the current study was to determine the effect of different methods of vital tooth bleaching (power in- office, at-home and over the counter) on the resistance of enamel to erosion and conclude whether bleached enamel is more vulnerable to erosion, when compared with non-bleached enamel surface.

\section{MATERIAL AND METHODS}

Freshly extracted bovine incisors were used in the current study. The teeth were sound and free from any developmental defects. They were stored in $0.1 \%$ Thymol solution after debridement. Then, they were placed in artificial saliva for 24 hours at $37^{\circ} \mathrm{C}$ prior to initiating the experiment. Square enamel sections $(4 \mathrm{~mm} \times 4 \mathrm{~mm} \times 3 \mathrm{~mm})$ were obtained from the middle third of the crown and then embedded in self-curing acrylic resin blocks (Acrostone-cold cure, Egypt) measuring ( $2 \mathrm{~cm}$ wide and $3 \mathrm{~cm}$ high) ${ }^{(40)}$. The surface was ground using a silicone carbide paper. The sequence started at P400 and successively increased to P1200 under a constant flow of water.

The samples were divided randomly into 4 groups according to the method of bleaching used. The materials used in the study and their composition are summarized in table 1.

The number of specimens was 36 per group; where 30 samples were used for energy-dispersive X-ray spectrometry (EDS) analysis and 6 samples were used as representative specimens for scanning electron microscope examination after each experimental step. The distribution of groups was as follow:

Group 1: control group All specimens of the control group were placed in artificial saliva at $37^{0} \mathrm{C}$ during the study period to simulate the oral condition.

Group 2: (power in- office bleaching) The gel was applied directly on the enamel surface of the specimens where the thickness of the gel was about 1-2 mm. The LED bleaching device (BT Cool Plus, Taiwan) with a wavelength of $430-490 \mathrm{~nm}$

Table 1: materials used in the study:

\begin{tabular}{|l|l|l|}
\hline Material & Composition & Manufacturer \\
\hline WHITE smile. Light Whitening AC & $\begin{array}{l}32 \% \text { hydrogen peroxide, Aqua, Silica, Glycerol, } \\
\text { Organic amines,Poly-glycols, and chlorophyll. }\end{array}$ & $\begin{array}{l}\text { WHITE smile GmbH } \\
\text { Birkenau } \\
\text { Germany }\end{array}$ \\
\hline $\begin{array}{l}\text { Frest 3D White Luxe Supreme } \\
\text { FlexFit Whitestrips (OTC) }\end{array}$ & $\begin{array}{l}5.3-5.6 \% \text { hydrogen peroxide, PVP, PEG-8,water, } \\
\text { glycerin, carbomer 956, sodium hydroxide , } \\
\text { Acryates Co-polymer and } \\
\text { Sodium saccharin. }\end{array}$ & $\begin{array}{l}\text { Crest, Procter \& Gamble } \\
\text { USA }\end{array}$ \\
\hline $\begin{array}{l}\text { Opalescence 15\%; take-home } \\
\text { whitening gel }\end{array}$ & $\begin{array}{l}\text { A 15\% carbamide peroxide gel, potassium nitrate } \\
\text { and fluoride. }\end{array}$ & $\begin{array}{l}\text { Ultradent Products Inc., South } \\
\text { Jordan, UT, USA) }\end{array}$ \\
\hline
\end{tabular}


and irradiance of $350 \mathrm{~mW} / \mathrm{cm}^{2}$ was used. The lamp was located close to enamel surface, then it was turned on for 15 minutes. This process was repeated three times and each time the bleaching gel was refreshed with a new one for a total application time 45 minutes. The gel was gently removed and then washed for about 1 minute with warm water.

Group 3: (Crest 3D White Luxe Supreme FlexFit Whitestrips (over the counter): The strips were applied to the enamel surface for 30 minutes twice daily for 14 days according to manufacturer instructions (41).

Group 4: (At-home bleaching): Bleaching gel was applied to the enamel surface. Teeth were placed for 6 hours at $37^{\circ} \mathrm{C}$ in a day according to the manufacturer's directions for 8 days (42).

After the bleaching process, the teeth were thoroughly rinsed under tap water and stored in artificial saliva $\left\{\mathrm{Nacl} 0.381(\mathrm{~g}) \mathrm{Kcl} 1.114(\mathrm{~g}), \mathrm{Cacl}_{2}\right.$ $0.231(\mathrm{~g}), \mathrm{KH}_{2} \mathrm{po}_{4} \quad 0.738(\mathrm{~g}), \mathrm{NaN}_{3} \quad 2.2(\mathrm{~g})$, Gastro Mucin 2.2(g)and Deionized Water 1000(g)\}(43).

Then, all the samples were subjected to erosive challenge. The bleached specimens and the specimens of control group were immersed in a solution of $1 \%$ citric acid where $\mathrm{pH}$ was equal to 3.6, under agitation, for a period of 5 minutes. After the erosion protocol, the specimens were stored in artificial saliva for 120 minutes. This succession was carried out twice per day for 3 successive days, with a total of 30 minutes of exposure to acid solution. The specimens were reserved in artificial saliva solution for 12 hours after each erosive protocol (40, 44). Mineral analysis via EDS was carried out before bleaching (base line), then of bleached enamel and finally after erosive cycle.

The EDS point analysis (JEOL, JSM-65LV scanning electron microscope, Tokyo Japan) figure (1a) was performed on the enamel surface to find out the elemental levels (wt\%) of $\mathrm{Ca}$, and $\mathrm{P}$ and the proportion between $\mathrm{Ca}$ and $\mathrm{P}$ was determined. For each sample, five points were randomly selected for measurement (300 $1 \mathrm{~m} 2$ for each point), and after that mean values were considered (45),

For analysis by scanning electron microscopy (SEM) (JEOL, JSM-65LV scanning electron microscope, Tokyo Japan), two representative samples of each group at each experimental step (initial, after bleaching and finally after erosion) were randomly selected and subjected to vacuum in a sputter coater (SPI-MOUDULE-Sputter Coater, West Chester, USA) figure (1b) to deposit a thin layer of gold, equivalent to $10 \_6 \mathrm{~mm}$, to raise the enamel surface reflectance. Then images of representative areas of the sample were recorded (35).

The obtained data of $\mathrm{Ca}$ and $\mathrm{P}$ levels (wt\%) concentration and the proportion between $\mathrm{Ca}$ and $P$ were statistically analyzed using SPSS version 20 including ANOVA, paired test and Tukey's test; where the level of significance ( $\mathrm{P}<0.001$ ).

\section{RESULTS:}

The value of the percentage weight of calcium $(\mathrm{Ca} \%)$ is presented in table (2). As shown in the table, there was no significant difference amongst the four tested groups regarding the weight of (Ca \%) value at base line (initial) measurements. The difference was significant after the bleaching procedure and after erosive cycle among the four tested groups where $\mathrm{p}<0.001$. The lowest percentage weight of calcium $(\mathrm{Ca} \%)$ values were recorded in group 2 (power in - office bleaching) either after bleaching or after erosive cycle in relation to other groups followed by group 3(Crest 3D White Luxe Supreme FlexFit Whitestrips (OTC), then group 2 (Opalescence 15\%; take-home whitening gel). Group 2 recorded the lowest percentage of calcium loss either after bleaching or after erosion compared with the groups 1 and 2.

Concerning statistical analysis of percentage weight of calcium (Ca \%) for each group, using Paired test, in relation to control group there was no significant difference between the percentage weight of calcium (Ca\%) level of initial value and the value at the second experimental step where 
there was no treatment (no bleaching). On the other hand, there was a reduction in percentage weight of calcium $(\mathrm{Ca} \%)$ level after erosion with no significant difference compared to initial records.

With regard to group 2 and group 3, there was a significant difference of percentage weight of calcium $(\mathrm{Ca} \%)$ level when comparison was carried out between initial and after bleaching, between bleached enamel and after erosion and between initial and after erosion.

Concerning group 4, there was significant difference when comparing initial measurements of percentage weight of calcium $(\mathrm{Ca} \%)$ and after bleaching and between the initial measurements and that after erosion.

On the other hand, the difference was not significant between percentage weight of calcium ( $\mathrm{Ca} \%)$ of bleached specimens and the eroded ones.

The difference of $(\mathrm{Ca} \%)$ concentration concerning group 4 was not significant when comparing initial measurement and after bleaching, and there was a reduction in $(\mathrm{Ca} \%)$ concentration after bleaching and after erosion. On the other hand, the difference between value of $(\mathrm{Ca} \%)$

TABLE (2) Comparison of percentage weight of calcium (Ca \%) for Energy-Dispersive X-ray Spectrometry (EDS) analysis of enamel surface.

\begin{tabular}{|c|c|c|c|c|c|c|c|}
\hline \multirow{2}{*}{\multicolumn{2}{|c|}{$\mathrm{Ca} \%$}} & \multicolumn{4}{|c|}{ Groups } & \multicolumn{2}{|c|}{ ANOVA } \\
\hline & & \multirow{2}{*}{$\begin{array}{c}\text { Control } \\
65.34 \\
-65.55\end{array}$} & \multirow{2}{*}{$\begin{array}{c}\begin{array}{c}\text { Power } \\
\text { (In-Office) } \\
\text { Bleaching }\end{array} \\
65.34 \\
-65.55\end{array}$} & \multirow{2}{*}{$\begin{array}{c}\begin{array}{c}\text { Over the } \\
\text { Counter } \\
\text { Bleaching }\end{array} \\
65.34 \\
-65.55 \\
\end{array}$} & \multirow{2}{*}{$\begin{array}{c}\begin{array}{c}\text { Home } \\
\text { bleaching }\end{array} \\
65.34 \\
-65.55\end{array}$} & \multirow{3}{*}{$\begin{array}{c}\mathbf{F} \\
0.000\end{array}$} & \multirow{3}{*}{$\begin{array}{c}\text { P-value } \\
\\
1.000\end{array}$} \\
\hline \multirow{2}{*}{$\begin{array}{c}\text { Initial } \\
\text { element \% }\end{array}$} & Range & & & & & & \\
\hline & Mean \pm SD & $\begin{array}{r}65.510 \\
\pm 0.038\end{array}$ & $\begin{array}{r}65.510 \\
\pm 0.038\end{array}$ & $\begin{array}{r}65.510 \\
\pm 0.038\end{array}$ & $\begin{array}{r}65.510 \\
\pm 0.038\end{array}$ & & \\
\hline \multirow{2}{*}{$\begin{array}{c}\text { Element \% } \\
\text { after } \\
\text { bleaching }\end{array}$} & Range & $\begin{array}{c}65.34 \\
-65.55\end{array}$ & $\begin{array}{c}38.36 \\
-40.75\end{array}$ & $\begin{array}{c}53.1 \\
-53.43\end{array}$ & $\begin{array}{c}60.84 \\
-60.98\end{array}$ & \multirow{2}{*}{26615.612} & \multirow{2}{*}{$<0.001^{*}$} \\
\hline & Mean \pm SD & $\begin{array}{c}65.510 \\
\pm 0.038\end{array}$ & $\begin{array}{c}39.174 \\
\pm 0.768\end{array}$ & $\begin{array}{c}53.194 \\
\pm 0.069\end{array}$ & $\begin{array}{l}60.917 \\
\pm 0.059\end{array}$ & & \\
\hline \multirow{2}{*}{$\begin{array}{c}\text { Element \% } \\
\text { after } \\
\text { erosion }\end{array}$} & Range & $\begin{array}{c}60.22 \\
-62.65\end{array}$ & $\begin{array}{c}28.34 \\
-29.76\end{array}$ & $\begin{array}{c}37.82 \\
-37.98\end{array}$ & $\begin{array}{c}53.1 \\
-53.43\end{array}$ & \multirow{2}{*}{36055.619} & \multirow{2}{*}{$<0.001 *$} \\
\hline & Mean \pm SD & $\begin{array}{r}61.737 \\
\pm 0.793\end{array}$ & $\begin{array}{r}29.594 \\
\pm 0.257\end{array}$ & $\begin{array}{r}37.863 \\
\pm 0.058\end{array}$ & $\begin{array}{l}53.194 \\
\pm 0.069\end{array}$ & & \\
\hline \multirow[t]{2}{*}{ I-AB } & Differences & $\begin{array}{c}0.000 \\
\pm 0.000\end{array}$ & $\begin{array}{c}26.336 \\
\pm 0.786\end{array}$ & $\begin{array}{c}12.315 \\
\pm 0.082\end{array}$ & $\begin{array}{c}4.593 \\
\pm 0.055\end{array}$ & & \\
\hline & Paired Test & 1.000 & $<0.001^{*}$ & $<0.001 *$ & $<0.001 *$ & & \\
\hline \multirow[t]{2}{*}{$\mathbf{I}-\mathbf{A E}$} & Differences & $\begin{array}{c}3.773 \\
\pm 0.802\end{array}$ & $\begin{array}{r}35.916 \\
\pm 0.255\end{array}$ & $\begin{array}{r}27.646 \\
\pm 0.078\end{array}$ & $\begin{array}{r}12.315 \\
\pm 0.082\end{array}$ & & \\
\hline & Paired Test & 0.314 & $<0.001 *$ & $<0.001 *$ & $<0.001 *$ & & \\
\hline \multirow[t]{2}{*}{ AB-AE } & Differences & $\begin{array}{c}3.773 \\
\pm 0.802\end{array}$ & $\begin{array}{c}9.580 \\
\pm 0.810\end{array}$ & $\begin{array}{c}15.331 \\
\pm 0.090\end{array}$ & $\begin{array}{c}7.723 \\
\pm 0.084\end{array}$ & & \\
\hline & Paired Test & 0.314 & $<0.001 *$ & $<0.001^{*}$ & 0.067 & & \\
\hline
\end{tabular}

*: significant, I :initial element \% measurement ,AB: after bleaching element \% measurement, AE : after erosion element $\%$ s measurement. 
concentration at initial measurement and after erosion was significant.

Table (3) shows the percentage weight of phosphorus (P \%) of the four tested groups at different experimental steps. There was a reduction in $(\mathrm{P} \%)$ values after bleaching and after erosion. The difference among the tested groups was significant. The comparison of percentage weight of phosphorus ( $\mathrm{P} \%)$ levels for each group was the same as the result of percentage weight of calcium $(\mathrm{Ca} \%)$ as well as the results of $(\mathrm{Ca} / \mathrm{P})$ ratio, as shown in table (4).
According to Tukey's test (table 5), which compared each two groups separately for percentage weight of calcium ( $\mathrm{Ca} \%)$, percentage weight of phosphorus (P \%), and percentage weight of calcium/phosphorus $(\mathrm{Ca} / \mathrm{P})$, there was a significant difference between group1 and group 2, group 2 and group 3, group 1and group 3, group 2 and 4 and finally between group 3 and group 4 either after bleaching or after erosion. Taking into account that there was no bleaching procedure in the control group, the difference between group 1 and group 4 was significant after bleaching (where there was

TABLE (3) Comparison of percentage weight of phosphorus (P\%) for Energy-Dispersive X-ray Spectrometry (EDS) analysis of enamel surface.

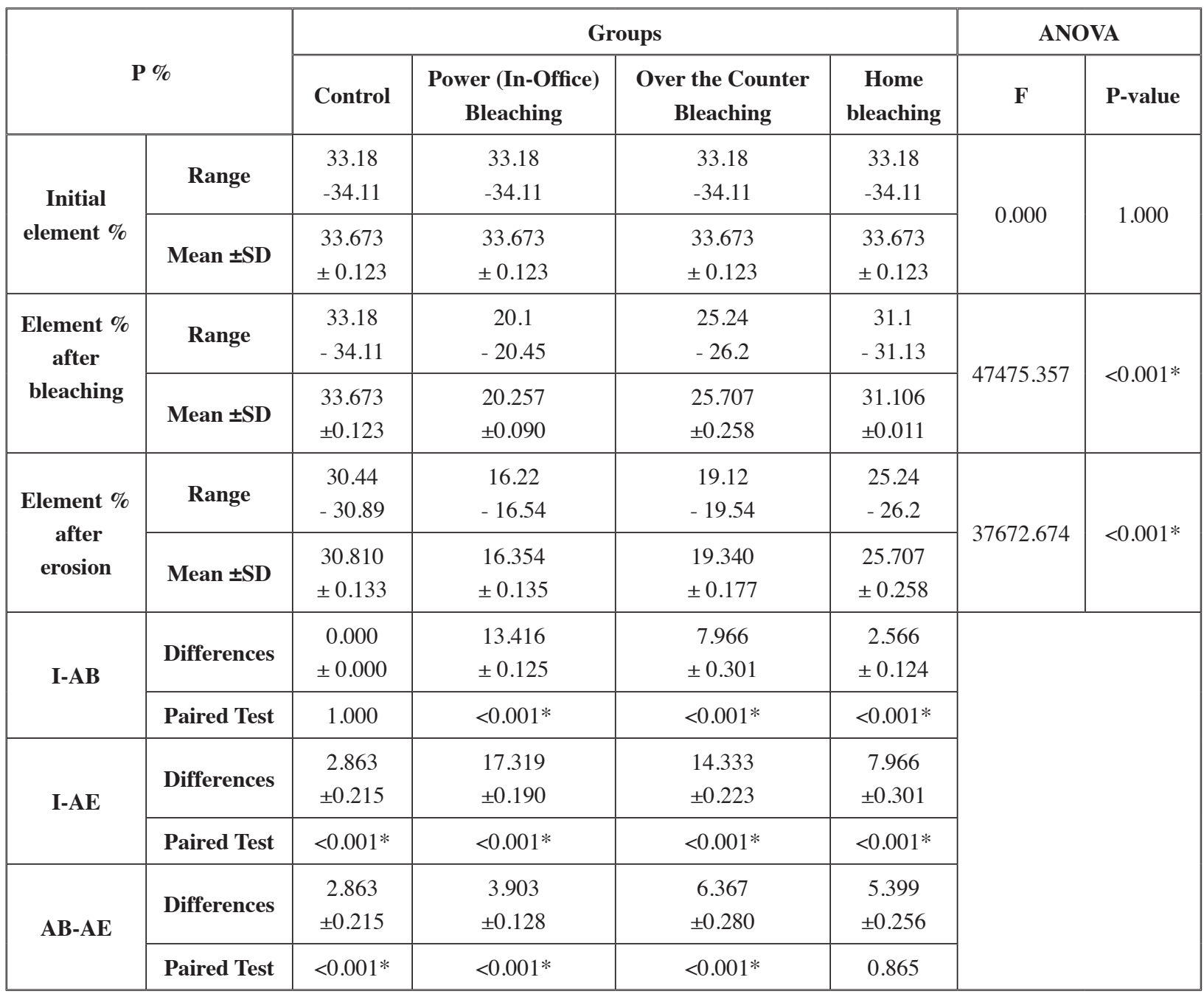


no bleaching in control group) but there was no significant difference between the two groups after erosive cycle. Figure (2) shows scanning electron microscope photomicrographs of group 1 before and after erosion since no bleaching procedure was carried out. Figures (3, 4 and 5) show scanning electron microscope photomicrographs of groups 2, 3 and 4 after bleaching and after erosion. Figure (6) shows EDS of group 1 before and after erosion where figures (7, 8 and 9) show EDS analysis of groups 2, 3 and 4 after bleaching and after erosion.

TABLE (4) Comparison of $(\mathrm{Ca} / \mathrm{P} \%)$ for Energy-Dispersive X-ray Spectrometry (EDS) analysis of enamel surface.

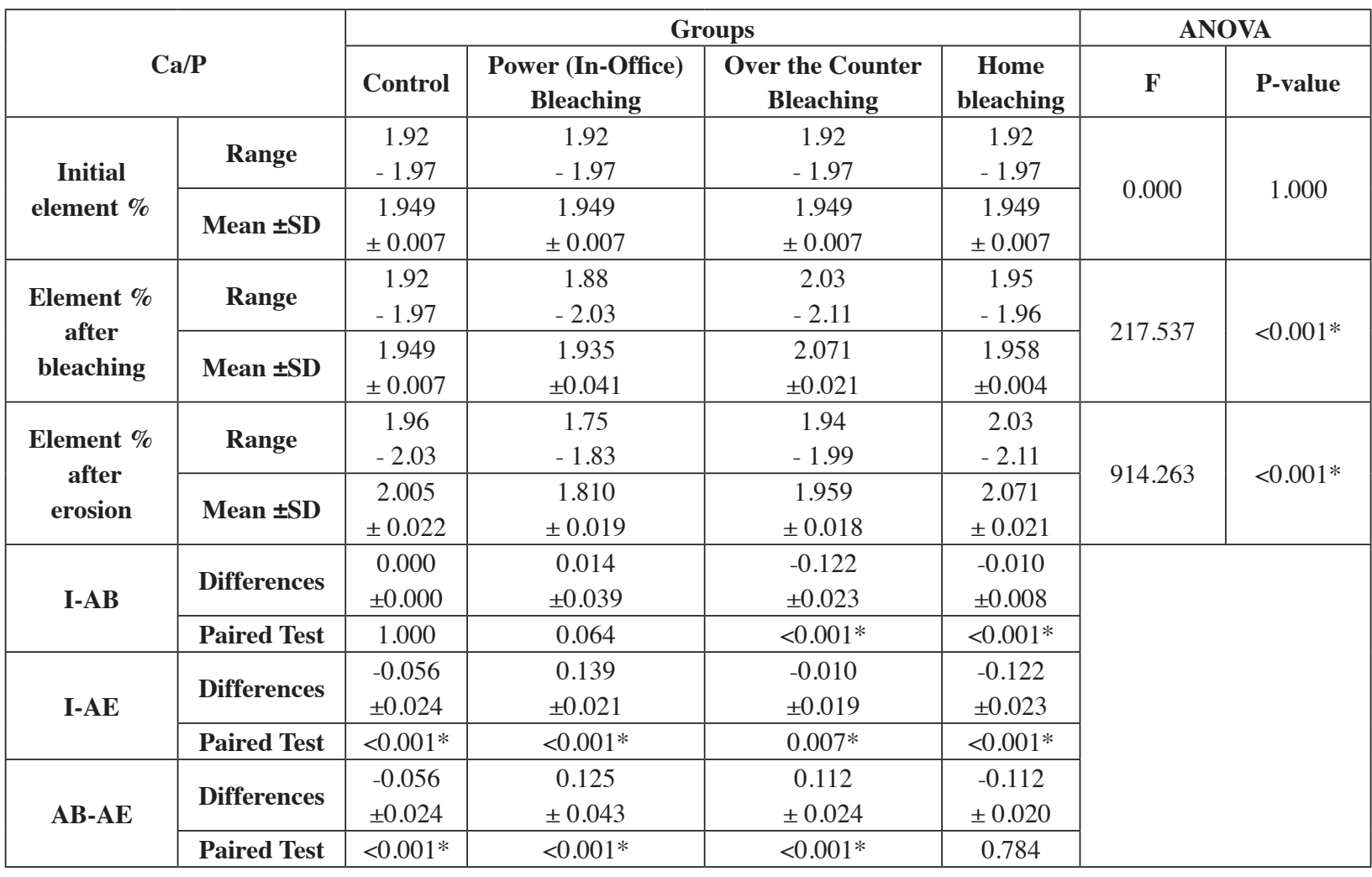

TABLE 5: Comparison of each two groups separately for $(\mathrm{Ca} \%)$, phosphorus $(\mathrm{P} \%)$ and $(\mathrm{Ca} / \mathrm{P} \%)$.

\begin{tabular}{|c|c|c|c|c|c|c|}
\hline \multicolumn{7}{|c|}{ TUKEY'S Test } \\
\hline & $1 \& 2$ & $1 \& 3$ & $1 \& 4$ & $2 \& 3$ & $2 \& 4$ & $3 \& 4$ \\
\hline Element $\%$ after bleaching $\mathrm{Ca} \%$ & $<0.001 *$ & $<0.001 *$ & $<0.001 *$ & $<0.001 *$ & $<0.001 *$ & $<0.001 *$ \\
\hline Element \% after erosion $\mathrm{Ca} \%$ & $<0.001 *$ & $<0.001 *$ & 0.108 & $<0.001 *$ & $<0.001 *$ & $<0.001 *$ \\
\hline Element \% after bleaching P\% & $<0.001 *$ & $<0.001^{*}$ & $<0.001 *$ & $<0.001 *$ & $<0.001 *$ & $<0.001 *$ \\
\hline Element $\%$ after erosion $\mathbf{P} \%$ & $<0.001 *$ & $<0.001 *$ & 0.105 & $<0.001^{*}$ & $<0.001 *$ & $<0.001 *$ \\
\hline Element $\%$ after bleaching $\mathrm{Ca} / \mathrm{P}$ & $<0.001 *$ & $<0.001 *$ & $<0.001 *$ & $<0.001 *$ & $0.001 *$ & $<0.001 *$ \\
\hline Element $\%$ after erosion $\mathrm{Ca} / \mathrm{P}$ & $<0.001 *$ & $<0.001 *$ & 0.374 & $<0.001 *$ & $<0.001 *$ & $<0.001 *$ \\
\hline
\end{tabular}




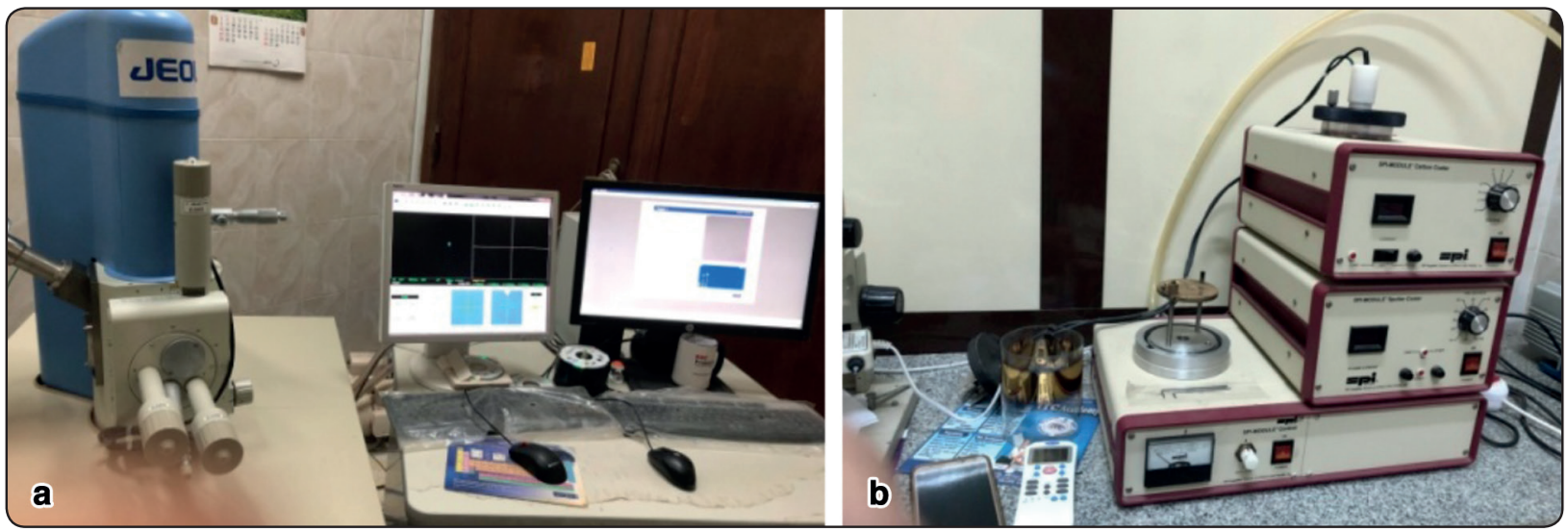

Fig. (1) Scanning Electron Microscope with Energy-Dispersive X-Ray Spectrometry (a), and sputter coater (b).

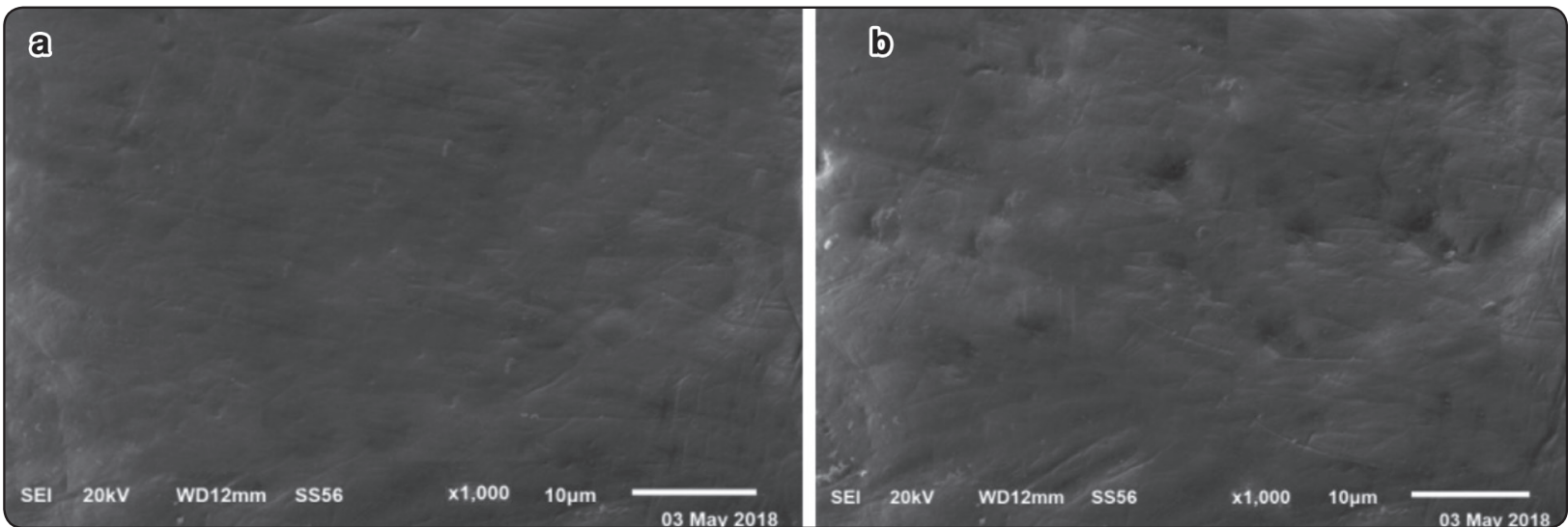

Fig. (2) Scanning electron microscope photomicrograph of group 1 (control group) before and after erosion (a and b) respectively.

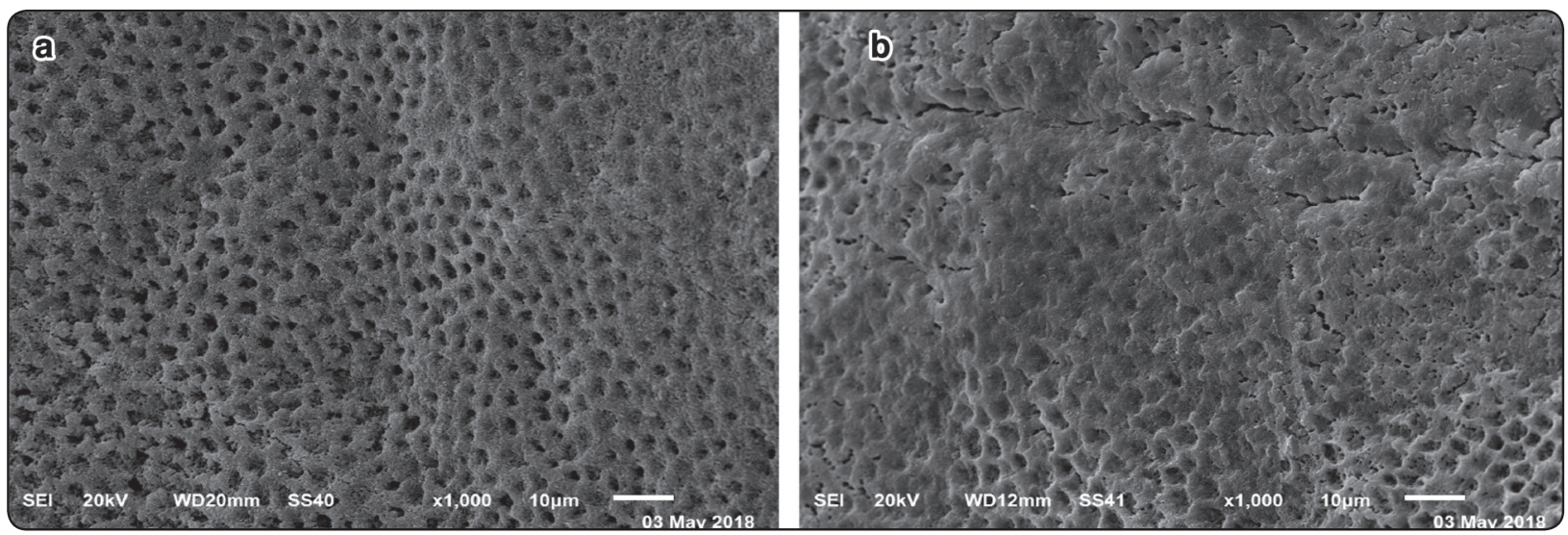

Fig. (3) Scanning electron microscope photomicrograph of group 2 (power in office) after bleaching and after erosion (a and b) respectively. 


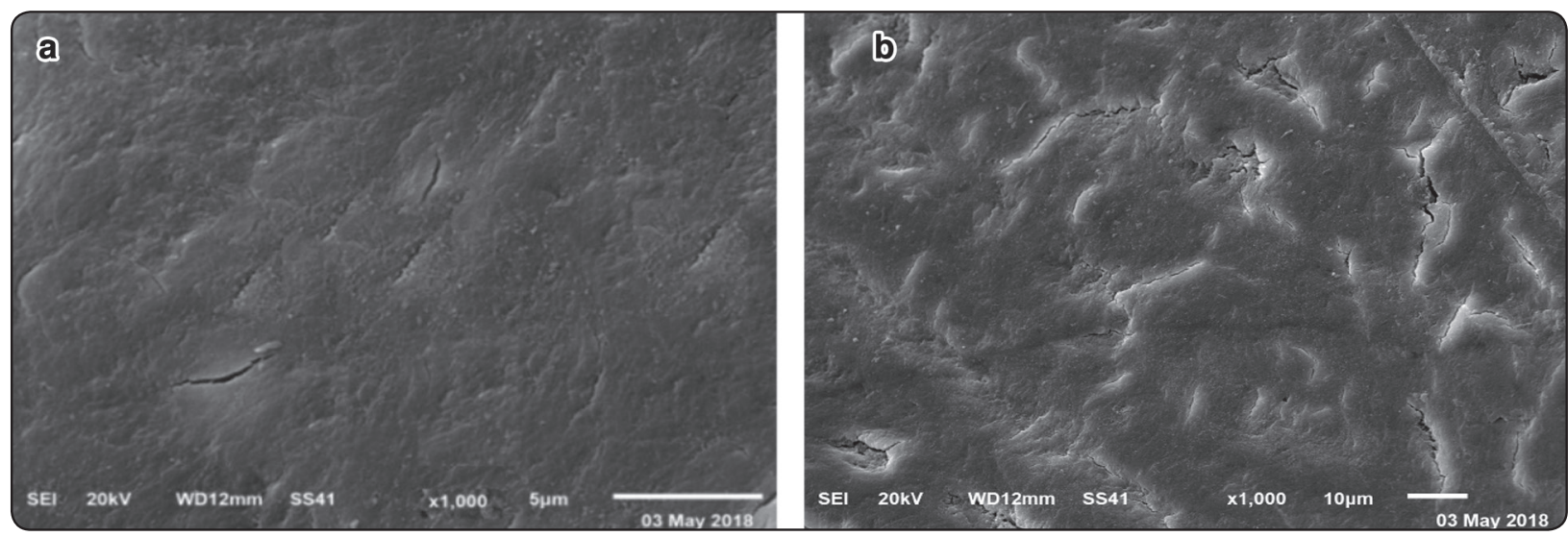

Fig. (4) Scanning electron microscope photomicrograph of group 3 (over the counter) after bleaching and after erosion (a and b) respectively.

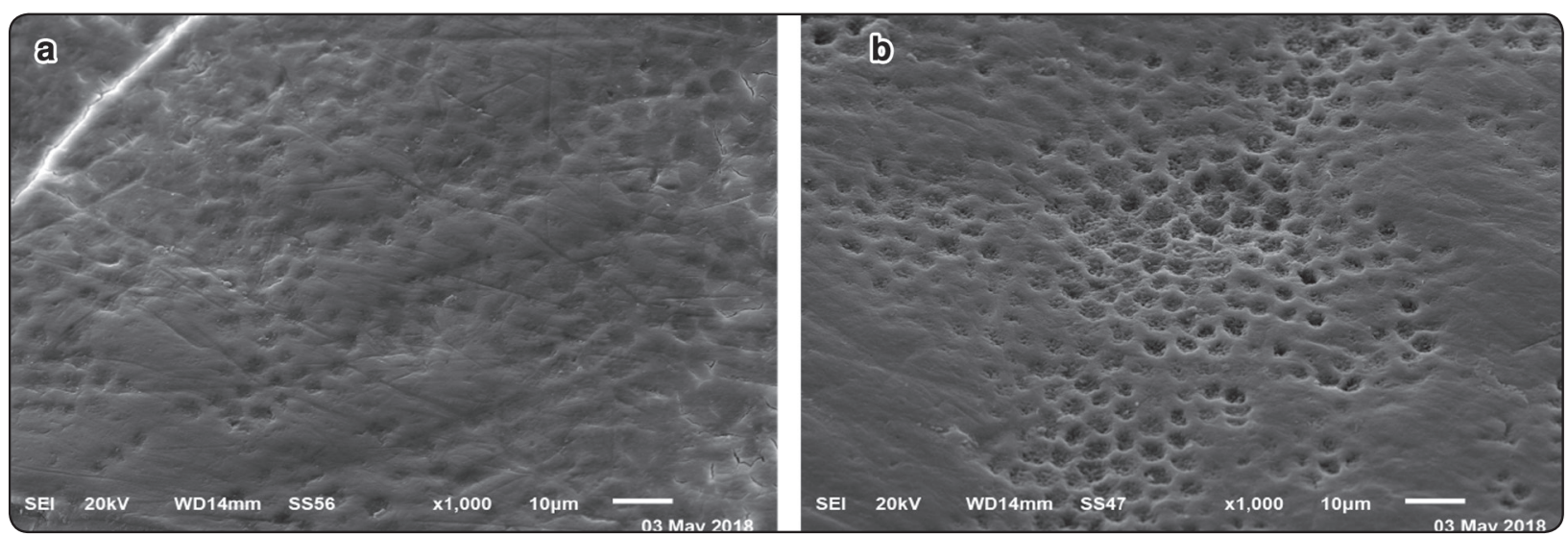

Fig. (5) Scanning electron microscope photomicrograph of group 4 (at- home bleaching) after bleaching and after erosion (a and b) respectively.

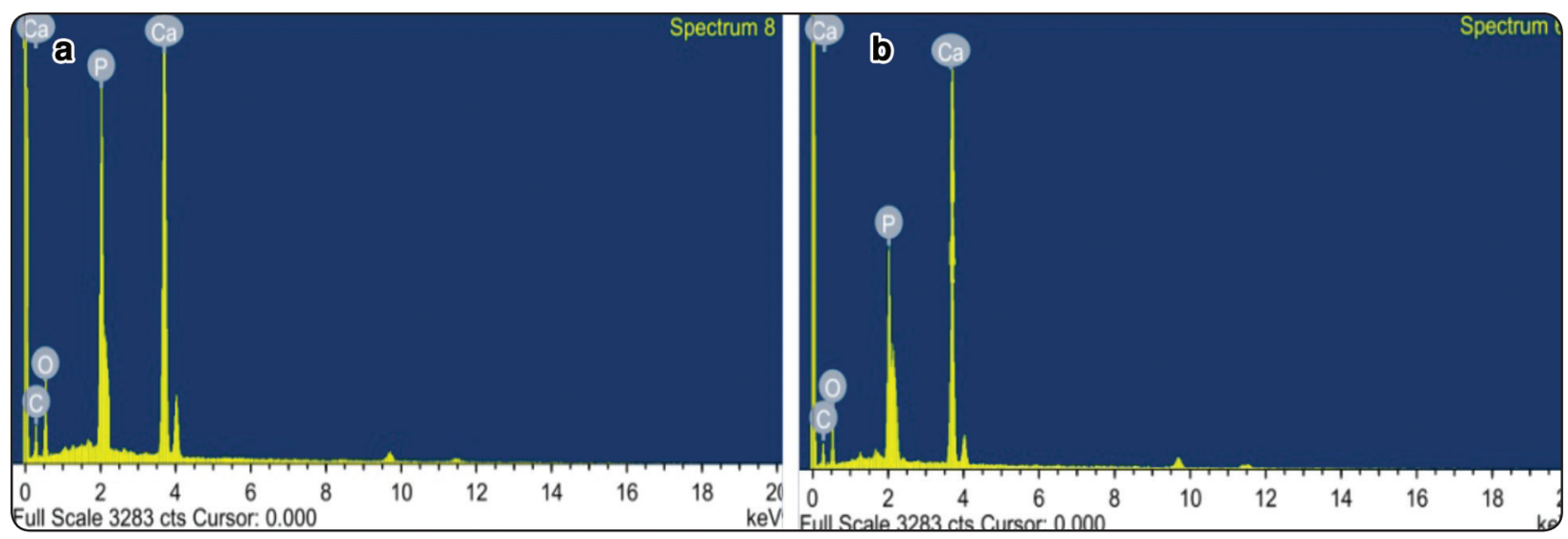

Fig. (6) EDS analysis of group (1) before and after erosion (a and b) respectively. 


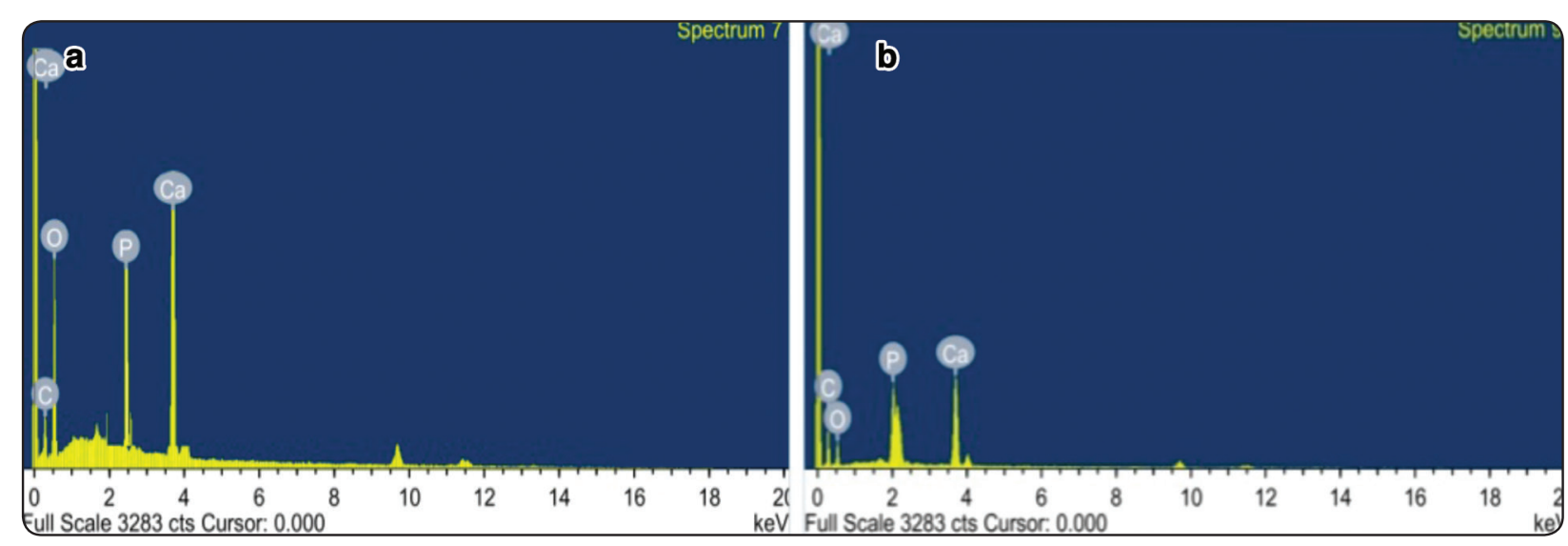

Fig. (7) EDS analysis of group (2) after bleaching and after erosion (a and b) respectively.

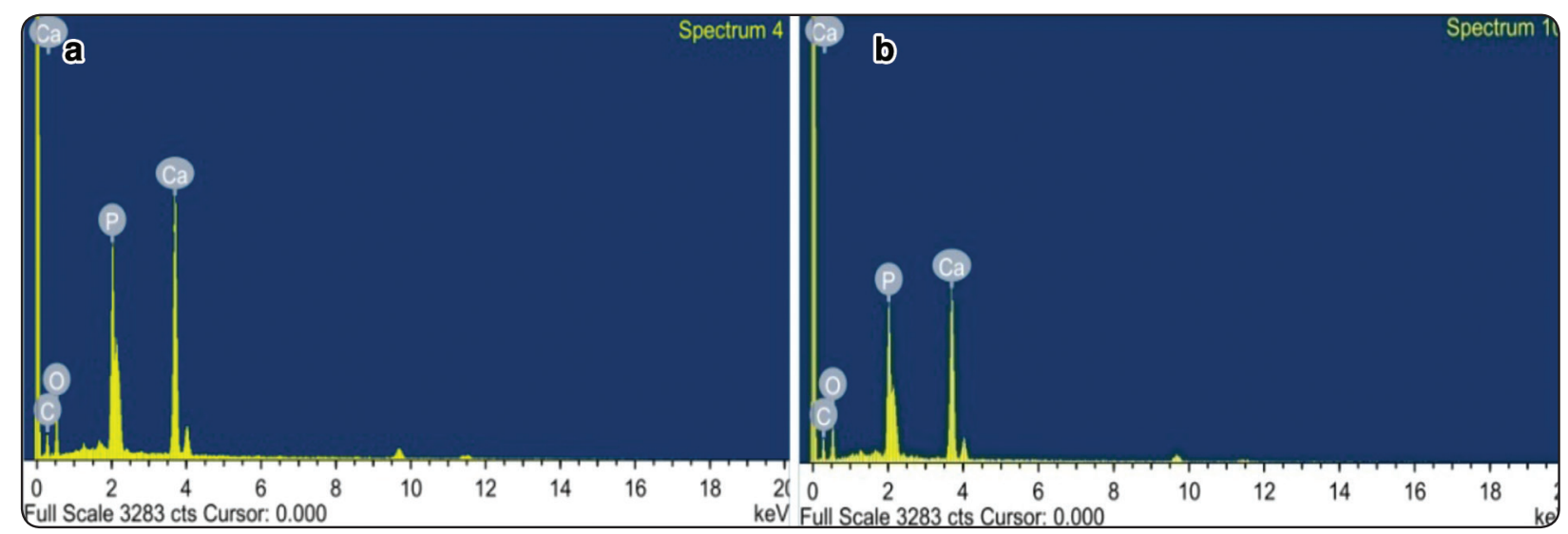

Fig. (8) EDS analysis of group (3) after bleaching and after erosion (a and b) respectively.

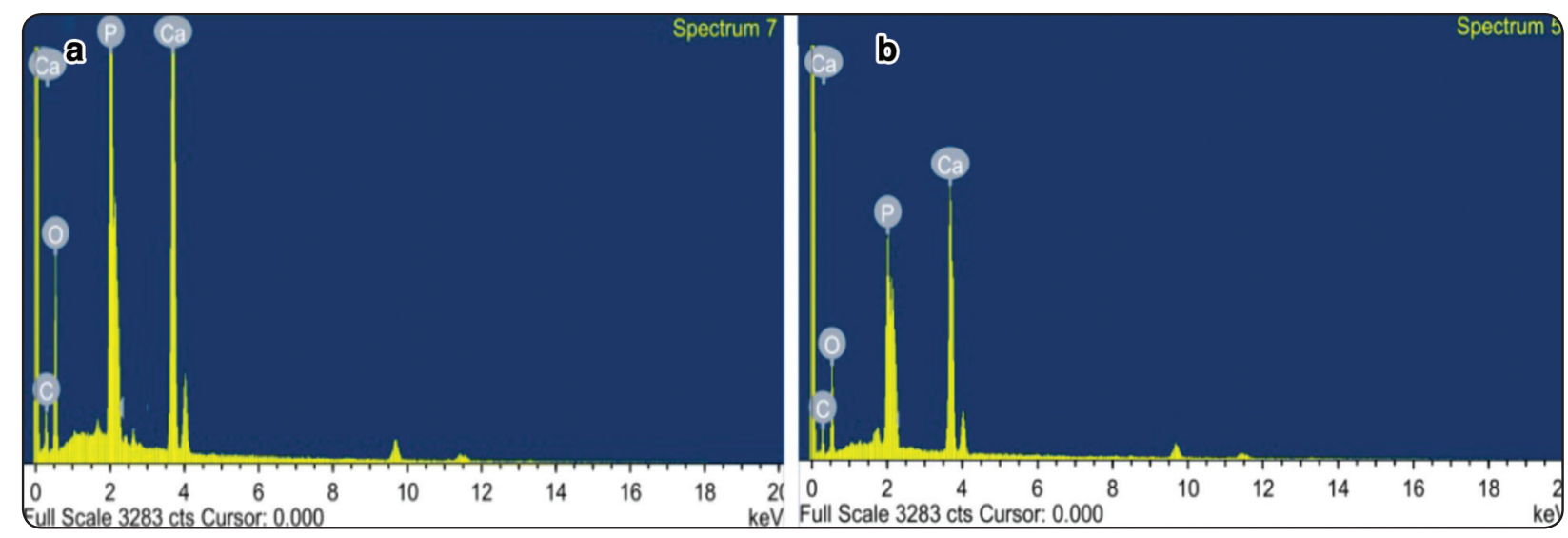

Fig. (9) EDS analysis of group (4) after bleaching and after erosion (a and b) respectively. 


\section{DISCUSSION}

Enamel is considered the hardest biological mineralized tissue, containing about $96 \%$ minerals, $3 \%$ water, and $1 \%$ organic matter by weight. The main inorganic constituent of enamel is hydroxylapatite which integrates numeral elements such as (Na, K, Cl, F, Mg, Zn, Pb, Cu, Sn, and Al) (46).

In the current study, bovine teeth were used since the physical and chemical morphology of enamel of bovine teeth resembles that of human enamel ${ }^{(47)}$.

Vital tooth bleaching protocols are considered efficient, less invasive, non destructive, and safe procedures for the management of teeth discoloration (48). "Power bleaching" (in-office) and "at-home bleaching" are considered the most commonly used vital bleaching techniques. In addition, over the counter products became prevalent and obtainable in different forms ${ }^{(49,50)}$.

One of the main side effect of bleaching procedures is loss of mineral content of enamel which is related to the release and liberation of calcium and phosphorus ions as a consequence of dissolution of hydroxyl-apatite crystals ${ }^{(51)}$. This adverse effect may be attributed to the act of free radicals resulting from the oxidation of the inorganic and organic elements on teeth and the acidic $\mathrm{pH}$ of the bleaching material applied ${ }^{(35,52)}$.

The loss of minerals leads to a decrease of enamel properties and its resistance to oral challenges such as erosion ${ }^{(53)}$. Erosive challenges carried out in the study simulate the action of acid substances present in beverages and food which are consumed regularly. Numerous studies investigated and analyzed the mineral loss resulting from bleaching procedures via measurement of enamel surface micro-hardness or roughness which are considered indirect methods for detection of the mineral loss of tooth structure ${ }^{(54-57)}$. On the other hand, one of the most accurate methods is the measurement of element concentration within enamel surface. In the current study, the essential point was to determine the effects of different vital bleaching methods and the effect of erosion on bleached enamel by analyzing the mineral content via Energy -Dispersive XRay Spectrometry (EDS) analysis method, and to determine the morphology of enamel surface via Scanning Electron Microscope examination ${ }^{(58-60)}$.

To distinguish between $\mathrm{Ca}$ and $\mathrm{P}$ loss as a consequence of bleaching, the current study included control groups. All the samples were kept in artificial saliva during the study in order to simulate physiological oral conditions as possible.

EDS analysis showed a decrease in $\mathrm{Ca} \%$ and $\mathrm{P}$ $\%$ values for all groups after the three methods of bleaching. The results were coincident with many other studies ${ }^{(45,51,52,61)}$. Even though $1 \%$ citric acid is not an ingredient of daily diet protocols; in vivo, it is considered a well-known and established method in erosion protocols in many studies ${ }^{(44,62,63)}$.

The percentage of loss of mineral content of enamel surface was significantly different among the tested groups. This result was different from the conclusion of the study carried out by Mansouri et al., 2017 where they found that, there was no significant changes on the properties of sound enamel after bleaching with $10 \% \mathrm{CP}$ for 8 hours and $30 \%$ HP for 30 minutes ${ }^{(64)}$. The findings of the current study are also not compatible with other preceding studies ${ }^{(65,66)}$. Some other studies have indicated that adverse effects can occur after bleaching procedure ${ }^{(67,68)}$. The dissimilar conclusions of the studies may be due to many factors as the type of specimens, media of storage, concentration of the bleaching agents applied, methodologies used to determine the bleaching effects, the time and duration of the bleaching agent application.

The loss of mineral content of enamel which appeared in the form of a decrease in percentage weight of calcium $(\mathrm{Ca} \%)$ and phosphorus $(\mathrm{P} \%)$ was markedly observed in power (in -office) group. This effect is almost dependent on the concentration of the bleaching agent ( $32 \%$ hydrogen peroxide) and light activation that could exacerbate and aggravate the enamel changes. The result came in agreement 
with a previous study which analyzed the effect of different light sources (LED, Diode Laser and neodymium-doped yttrium aluminium garnet Laser) on the micro-hardness of enamel submitted to bleaching with $35 \% \mathrm{HP}$ and observed a decrease in the enamel micro-hardness in all groups of power in office bleaching groups ${ }^{(69)}$. On the other hand, other studies revealed that light activation during inoffice bleaching did not produce significant changes in the enamel compared to a non-light-activated technique ${ }^{(70)}$. In the study carried out by Mondelli et al., (2015) it was found that the light activation did not present a significant influence on the microhardness values which was indirectly related to mineral loss, independent of light source ${ }^{(69)}$. Parreiras et al., in 2014, also reported insignificant enamel changes comparing light activated and non light activated bleaching protocols right after the bleaching process. They also reported that, after one week of storage in artificial saliva, all the specimen micro-hardness values were comparable to their initial values. The distinction in results may be attributed to the difference of light source used in the bleaching procedure ${ }^{(70)}$.

Dionysopoulos et al., (2017) found that a slight reduction in enamel surface micro-hardness and changes in surface morphology may occur when high-concentrated bleaching agents were used for power in-office tooth bleaching and there was acceleration in bleaching process. Dissimilarity in results may be attributed to difference in source of activation, where in the current study LED was used whereas Er,Cr:YSGG laser was used in the other study which advised the use of Er,Cr:YSGG laser in-office tooth bleaching safely ${ }^{(71)}$.

A preceding study found that bleaching agents with high-concentration damage enamel surface ${ }^{(72)}$. On the other hand, the study also found that enamel deterioration was reversible and could be repaired by the using the remineralizing agents. In this circumstance, fluoride is considered the most popular and important material to support mineral equilibrium, decreasing demineralization and activating remineralization. This leads to formation of fluoro-hydroxy-apatite, which is more resistant to solubility in acidic solutions than hydroxyl-apatite. In the current study, there was no use of remineralizing agents after bleaching which explained the irreversible loss of mineral of bleached enamel and decreased its resistance to erosion especially in group 2 and group 3.

Another study reported that bleaching agents containing sodium fluoride or calcium gluconate had higher micro-hardness values than other bleaching agents that did not contain these remineralizing materials ${ }^{(73)}$. According to those authors, calcium gluconate in high-concentrated agents exhibited a constructive effect on enamel surface. However, the study described that the effects of calcium gluconate were still on debate as this material was irreconcilable with strong oxidizing agents. The authors reported that free radicals released through bleaching (free oxygen and per-hydroxyl) could be inhibited by the calcium gluconate. Power (InOffice) bleaching material used in our study did not contain fluoride or calcium, where at -home bleaching agent contained fluoride which may be an explanation of the results we obtained where athome bleaching group showed the lowest mineral loss and more resistance to erosion. In the current study, despite that in home bleaching exhibited the lowest mineral loss compared to the other tested groups, the mineral loss happened and the difference was significant in comparison to the initial values. Results of other studies which are not consistent with the results of our study have shown that there was no significant changes in enamel surface postbleaching when using carbamide peroxide (74-77). In addition, De Geus et al., (2018) stated that athome bleaching with 10\% Carbamide Peroxide showed similar bleaching efficacy with lower risk and intensity of tooth sensitivity in comparison with more concentrated carbamide peroxide gels. Tooth sensitivity reflects the changes and alteration that occur in enamel resulting from bleaching ${ }^{(78)}$. This difference in results may be attributed to difference 
in concentration of bleaching material used where our study used $15 \%$ carbamide peroxide where other studies used $10 \%$ carbamide peroxide. On the other hand, others have reported structural changes that occur with carbamide peroxide which corresponds to the results of the current study. These studies found that both $10 \%$ and $16 \% \mathrm{CP}$ bleaching gels reduced the mineral content and increased the surface roughness of dental enamel, producing a more irregular and porous surface. However, the $16 \%$ CP gel promoted the most intense alterations on enamel, even after a single 8-hours application. This finding matched with current results where the concentration of carbamide peroxide was $15 \%{ }^{(79-82)}$.

Both over the counter whitening strips and athome bleaching showed mineral loss and surface alteration compared to the control group. These results are consistent with the study carried out by Cordeiro et al., (2018) ${ }^{(83)}$. In the current study, mineral loss and surface alteration resulting from bleaching with Crest 3D White strips were significantly higher than that created after at-home bleaching. These findings were in contrary to the results obtained by the study carried out by Singh et al., (2018), where they compared the microhardness and surface roughness of the human natural tooth after bleaching treatment with a professional at-home bleaching and over-the counter (OTC) bleaching agent ${ }^{(84)}$. The difference in results may be attributed to the different way of measuring changes in the enamel surface, where the measurement of $\mathrm{Ca}$ $\%$ and $\mathrm{P} \%$ loss may be more sensitive to measure the degree of change in enamel surface and the change in study methodology related to Crest 3D White strips.

On the other hand, the results of current study came in coincidence with another study in part where it was found that alteration of enamel significantly was increased in the OTC group as this study evaluated the effect of four whitening modalities on enamel surface ${ }^{(40)}$. But the results were different in another part, where the enamel surface alteration in the current study created by over the counter strips was less than that created by power in-office bleaching method. This may be attributed to the difference in the in-office tooth bleaching protocol used in the other study, which appeared through more $\mathrm{Ca}$ and $\mathrm{P}$ loss.

In the step of erosion after bleaching, the $\mathrm{Ca}$ $\%, \mathrm{P} \%$ and $\mathrm{Ca} / \mathrm{P} \%$ values were significantly lower in the power in-office beaching group when compared with the other groups, followed by the group bleached with Crest 3D White strips, whereas the difference was not significant between at-home bleaching group and control group. The results came in agreement with previous studies, the findings of the results related to this point indicated that resistance of enamel to erosion was markedly observed in control group followed by at-home bleaching group, then over the counter, and finally in- office bleaching group which showed the lowest resistance to erosion .

The results came in agreement with another study which showed that the enamel bleached with $35 \% \mathrm{H}_{2} \mathrm{O}_{2}$ or $7.5 \% \mathrm{H}_{2} \mathrm{O}_{2}$ was in the groups that generated the highest loss of surface hardness, which indirectly related to mineral loss of enamel surface $^{(62)}$. This showed that the concentration of the $\mathrm{H}_{2} \mathrm{O}_{2}$, as a single reason, was not determinant in decreasing the enamel micro-hardness. On the other hand, the results of current study were not compatible with previous studies where there was no significant loss of minerals after erosion ${ }^{(85,86)}$. The difference in findings may be due to the addition of calcium in the bleaching agents in the other study.

The enamel surface bleached with at-home bleaching method exhibited resistance to erosion when compared to other bleaching methods. The results were different from the study carried out by Elfallah et al., (2015) who affirmed that tooth bleaching agents either carbamide peroxide or hydrogen peroxide can lead to detrimental effects on the properties of enamel surface. The produced effects may result from damaging or denaturing its protein ${ }^{(29)}$. The possible explanation of the results 
may be that the material of at-home bleaching used in the current study contained fluoride in its composition. In addition, resistance to erosion was indirectly proportional to the loss of minerals at bleaching procedure. So, the at-home bleaching exhibited the lowest loss of minerals after bleaching and the enamel in this group showed higher resistance to erosion ${ }^{(87)}$.

\section{CONCLUSIONS}

Under the limitations of this study we can conclude the following:

1- At-home beaching is considered the least harmful to enamel compared to power in- office and over the counter bleaching materials and it is more resistant to erosive challenges.

2- Bleaching agents containing calcium decrease the adverse effects of bleaching procedure.

3- Bleached enamel is less resistant to erosion especially when power in office or over the counter protocol is used.

\section{RECOMMENDATIONS}

1- Caution should be advised to the general public when using over the counter bleaching products as it may adversely affect enamel.

2- It is recommended to avoid acidic dietary substances after bleaching procedure.

3- It recommended to use bleaching agents containing calcium or fluoride to decrease the adverse effects of bleaching agent.

4- It is recommended to use a remineralizing agent after the bleaching procedure

\section{REFERENCES}

1. Chan M, Mehta S, Banerji S. An evaluation of the influence of teeth and the labial soft tissues on the perceived aesthetics of a smile. British dental journal. 2017;223(4):272.

2. Serraglio CR, Zanella L, Dalla-Vecchia KB, RodriguesJunior SA. Efficacy and safety of over-the-counter whitening strips as compared to home-whitening with $10 \%$ carbamide peroxide gel-systematic review of RCTs and metanalysis. Clinical oral investigations. 2016;20(1):1-14.

3. Joiner A. Tooth colour: a review of the literature. Journal of dentistry. 2004;32:3-12.

4. Nutter BJ, Sharif MO, Smith AB, Brunton PA. A clinical study comparing the efficacy of light activated in-surgery whitening versus in-surgery whitening without light activation. Journal of dentistry. 2013;41:e3-e7.

5. Jaime I, França F, Basting RT, Turssi CP, Amaral F. Efficacy of hydrogen-peroxide-based mouthwash in altering enamel color. Am J Dent. 2014;27(1):47-50.

6. Joiner A. The bleaching of teeth: a review of the literature. Journal of dentistry. 2006;34(7):412-9.

7. López ID, Novoa L. Efficacy of different protocols for at-home bleaching: A randomized clinical trial. American journal of dentistry. 2017;30(6):329-34.

8. Maran BM, Burey A, de Paris Matos T, Loguercio AD, Reis A. In-office dental bleaching with light vs. without light: A systematic review and meta-analysis. Journal of dentistry. 2017.

9. Kielbassa AM, Maier M, Gieren A-K, Eliav E. Tooth sensitivity during and after vital tooth bleaching: A systematic review on an unsolved problem. Quintessence international. 2015;46(10).

10. Kwon SR, Wertz PW. Review of the mechanism of tooth whitening. Journal of Esthetic and Restorative Dentistry. 2015;27(5):240-57.

11. Carey CM. Tooth whitening: what we now know. Journal of Evidence-Based Dental Practice. 2014;14:70-6.

12. Martín J, Vildósola P, Bersezio C, Herrera A, Bortolatto $\mathrm{J}$, Saad J, et al. Effectiveness of $6 \%$ hydrogen peroxide concentration for tooth bleaching-A doubleblind, randomized clinical trial. Journal of dentistry. 2015;43(8):965-72.

13. Sulieman M, Addy M, MacDonald E, Rees J. The effect of hydrogen peroxide concentration on the outcome of tooth whitening: an in vitro study. Journal of dentistry. 2004;32(4):295-9.

14. Esmaeili B, Abolghasemzadeh F, Gholampor A, Daryakenari G. The effect of home bleaching carbamide peroxide concentration on the microhardness of dental composite resins. General dentistry. 2018;66(1):40-4. 
15. Monteiro MJF, Lindoso JBC, de Oliveira Conde NC, da Silva LM, Loguercio AD, Pereira JV. Evaluation of the genotoxic potential of different delivery methods of athome bleaching gels: a single-blind, randomized clinical trial. Clinical oral investigations. 2018:1-8.

16. Loguercio AD, Martins LM, da Silva LM, Reis A. InOffice Whitening. Tooth Whitening: Springer; 2016. p. 145-67.

17. Boushell LW, Ritter AV, Garland GE, Tiwana KK, Smith LR, Broome A, et al. Nightguard vital bleaching: side effects and patient satisfaction 10 to 17 years posttreatment. Journal of Esthetic and Restorative Dentistry. 2012;24(3):211-9.

18. Nie J, Tian F-C, Wang Z-H, Yap AU, Wang X-Y. Comparison of efficacy and outcome satisfaction between in-office and home teeth bleaching in Chinese patients. Journal of oral science. 2017;59(4):527-32.

19. Demarco FF, Meireles SS, Masotti AS. Over-the-counter whitening agents: a concise review. Brazilian oral research. 2009;23:64-70.

20. Takesh T, Sargsyan A, Lee M, Anbarani A, Ho J, WilderSmith P. Evaluating the Whitening and Microstructural Effects of a Novel Whitening Strip on Porcelain and Composite Dental Materials. Dentistry (Sunnyvale, Calif). 2017;7(8).

21. Kwon SR, Wang J, Oyoyo U, Li Y. Evaluation of bleaching efficacy and erosion potential of four different over-thecounter bleaching products. American journal of dentistry. 2013;26(6):356-60.

22. Horn BA, Bittencourt BF, Gomes OMM, Farhat PA. Clinical evaluation of the whitening effect of over-thecounter dentifrices on vital teeth. Brazilian dental journal. 2014;25(3):203-6.

23. Ghalili KM, Khawaled K, Rozen D, Afsahi V. Clinical study of the safety and effectiveness of a novel over-thecounter bleaching tray system. Clinical, cosmetic and investigational dentistry. 2014;6:15.

24. Brooks JK. Chemical burn to the gingiva after misuse of an over-the-counter oral whitening mouthwash. General dentistry. 2017;65(1):34-6.

25. Majeed A, Grobler SR, Moola MH, Oberholzer T. Effect of four over-the-counter tooth-whitening products on enamel microhardness: scientific. South African Dental Journal. 2011;66(9):412-5.
26. Li Y, Greenwall L. Safety issues of tooth whitening using peroxide-based materials. British dental journal. 2013;215(1):29.

27. Diklić D, Sever EK, Galić N, Spajić J, Prskalo K. Attitudes of Students of Differenet Schools of University of Zagreb on Tooth Bleaching. Acta stomatologica Croatica. 2016;50(4):301.

28. Cakir F, Korkmaz Y, Firat E, Oztas S, Gurgan S. Chemical analysis of enamel and dentin following the application of three different at-home bleaching systems. Operative dentistry. 2011;36(5):529-36.

29. Elfallah HM, Bertassoni LE, Charadram N, Rathsam C, Swain MV. Effect of tooth bleaching agents on protein content and mechanical properties of dental enamel. Acta biomaterialia. 2015;20:120-8.

30. FARAONI-ROMANO JJ, Da Silveira AG, Turssi CP, Serra MC. Bleaching agents with varying concentrations of carbamide and/or hydrogen peroxides: effect on dental microhardness and roughness. Journal of Esthetic and Restorative Dentistry. 2008;20(6):395-402.

31. Maia E, Baratieri LN, de Andrada MAC, Monteiro Jr S, Vieira LCC. The influence of two home-applied bleaching agents on enamel microhardness: an in situ study. Journal of dentistry. 2008;36(1):2-7.

32. Magalhães JG, Marimoto ÂR, Torres CR, Pagani C, Teixeira SC, Barcellos DC. Microhardness change of enamel due to bleaching with in-office bleaching gels of different acidity. Acta Odontologica Scandinavica. 2012;70(2):122-6.

33. Pinto CF, Oliveira Rd, Cavalli V, Giannini M. Peroxide bleaching agent effects on enamel surface microhardness, roughness and morphology. Brazilian Oral Research. 2004;18(4):306-11.

34. Abouassi T, Wolkewitz M, Hahn P. Effect of carbamide peroxide and hydrogen peroxide on enamel surface: an in vitro study. Clinical oral investigations. 2011;15(5): $673-80$.

35. Shankar S, Jagannathan N, Jain AR. Ultrastructural changes in dental tissues following exposure to hydrogen peroxide. Journal of Pharmacy Researchl Vol. 2018;12(2):216.

36. Scimeca M, Bischetti S, Lamsira HK, Bonfiglio R, Bonanno E. Energy Dispersive X-ray (EDX) microanalysis: A powerful tool in biomedical research and diagnosis. European journal of histochemistry: EJH. 2018;62(1). 
37. Huysmans M, Chew H, Ellwood R. Clinical studies of dental erosion and erosive wear. Caries research. 2011; 45(Suppl. 1):60-8.

38. Lussi A, Carvalho TS. The future of fluorides and other protective agents in erosion prevention. Caries research. 2015;49(Suppl. 1):18-29.

39. Vasconcelos M, Fonseca-Gonçalves A, de Medeiros UV, Maia LC, Queiroz CS. An In Vitro Evaluation of Human Enamel Surfaces Subjected to Erosive Challenge After Bleaching. Journal of Esthetic and Restorative Dentistry. 2017;29(2):128-36.

40. Kwon SR, Kurti SR, Oyoyo U, Li Y. Effect of various tooth whitening modalities on microhardness, surface roughness and surface morphology of the enamel. Odontology. 2015;103(3):274-9.

41. Karadas M, Duymus ZY. In vitro evaluation of the efficacy of different over-the-counter products on tooth whitening. Brazilian dental journal. 2015;26(4):373-7.

42. Cansunar HA, Guven Y, Dogan F. The effect of different bleaching materials on the solubility of enamel. Medicine. 2017;6(1):57-61.

43. Austin R, Giusca C, Macaulay G, Moazzez R, Bartlett D. Confocal laser scanning microscopy and area-scale analysis used to quantify enamel surface textural changes from citric acid demineralization and salivary remineralization in vitro. Dental Materials. 2016;32(2):278-84.

44. Karlinsey RL, Mackey AC, Blanken DD, Schwandt CS. Remineralization of eroded enamel lesions by simulated saliva in vitro. The open dentistry journal. 2012;6:170.

45. Vieira-Junior W, Ferraz L, Pini N, Ambrosano G, Aguiar F, Tabchoury C, et al. Effect of Toothpaste Use Against Mineral Loss Promoted by Dental Bleaching. Operative dentistry. 2018;43(2):190-200.

46. Kano Y, Nakajima M, Aida A, Seki N, Foxton RM, Tagami $\mathrm{J}$. Influence of enamel prism orientations on color shifting at the border of resin composite restorations. Dental materials journal. 2018;37(2):341-9.

47. Trentino AC, Azevedo LM, da Silva FFF, de Almedra Freitas MCC, Borges MSA, Mondelli RFL. Evaluation of surface roughness and color change of bovine enamel after immersion in dye solution. Journal of Research in Dentistry. 2018;5(5):95-105.

48. Polydorou O, Scheitza S, Spraul M, Vach K, Hellwig E. The effect of long-term use of tooth bleaching products on the human enamel surface. Odontology. 2018;106(1):64-72.
49. Tam LE, Kim N, De Souza GM. Effect of tooth whitening strips on fatigue resistance and flexural strength of bovine dentin in vitro. PloS one. 2017;12(3):e0173480.

50. Mounika A, Mandava J, Roopesh B, Karri G. Clinical evaluation of color change and tooth sensitivity with inoffice and home bleaching treatments. Indian Journal of Dental Research. 2018;29(4):423.

51. Moreira RF, Santos FP, Santos EA, Santos RSd, Anjos MJd, Miranda MSd. Analysis of the Chemical Modification of Dental Enamel Submitted to 35\% Hydrogen Peroxide "InOffice" Whitening, with or without Calcium. International journal of dentistry. 2017;2017.

52. Andrade AP, Shimaoka AM, Cardoso MV, Carvalho RCR. Effects of different degrees of acidity and concentration of bleaching agents on human enamel mineral content and surface morphology over time. Brazilian Dental Science. 2018;21(1):54-63.

53. Mullan F, Austin RS, Parkinson CR, Bartlett DW. An insitu pilot study to investigate the native clinical resistance of enamel to erosion. Journal of dentistry. 2018;70:124-8.

54. Carlos N, Amaral F, França F, Turssi C, Basting R. Staining solutions and bleaching agents: Enamel microhardness and roughness effects. Dental Materials. 2017;33:e16.

55. Branco A, Polido M, Serro A, Figueiredo-Pina C, editors. Study of The Effect Of H2o2 Used In Whitening Treatments on Human Enamel Wear Resistance. International Scientific Conference BALTTRIB; 2018.

56. Rodrigues J, Erhardt MCG, Marchi GM, Pimenta L, Ambrosano GMB. Association effect of in-office and nightguard vital bleaching on dental enamel microhardness. Brazilian Journal of Oral Sciences. 2016:365-9.

57. Zanolla J, Marques A, da Costa D, de Souza A, Coutinho M. Influence of tooth bleaching on dental enamel microhardness: a systematic review and meta-analysis. Australian dental journal. 2017;62(3):276-82.

58. Sorozini M, Dos Santos R, Silva E, Dos Anjos M, Perez C. Assessment of $\mathrm{Ca}$ and $\mathrm{P}$ content variation in enamel during an eight-week bleaching protocol using energy dispersive X-ray fluorescence. Spectrochimica Acta Part B: Atomic Spectroscopy. 2017;131:93-8.

59. Klaric E, Rakic M, Sever I, Milat O, Par M, Tarle Z. Enamel and dentin microhardness and chemical composition after experimental light-activated bleaching. Operative dentistry. 2015;40(4):E132-E41. 
60. Farawati FA, Hsu S-M, O’Neill E, Neal D, Clark A, Esquivel-Upshaw J. Effect of carbamide peroxide bleaching on enamel characteristics and susceptibility to further discoloration. The Journal of prosthetic dentistry. 2018.

61. Llena C, Esteve I, Forner L. Effects of in-office bleaching on human enamel and dentin. Morphological and mineral changes. Annals of Anatomy-Anatomischer Anzeiger. 2018;217:97-102.

62. de Fátima Carvalho Vasconcelos M, Fonseca-Gonçalves A, de França aKA, De Medeiros UV, Maia LC, Queiroz CS. An In Vitro Evaluation of Human Enamel Surfaces Subjected to Erosive Challenge After Bleaching. Journal of Esthetic and Restorative Dentistry. 2017;29(2):128-36.

63. Fowler C, Lynch R, Shingler D, Walsh D, Carson C, Neale A, et al. A Novel Electron-Microscopic Method for Measurement of Mineral Content in Enamel Lesions. Archives of oral biology. 2018.

64. Mansouri RS, Khzam N. Hydrogen Peroxide Tooth Whitening Agent Effect on the Nanomechanical Properties of Enamel. Journal of Research in Medical and Dental Science. 2017;5(2):91-101.

65. Jr GP, Zaidel L, Lin N, Stranick M, Bagley D. High Levels of Hydrogen Peroxide in Overnight Tooth-Whitening Formulas: Effects on Enamel and Pulp. Journal of Esthetic and Restorative Dentistry. 2005;17(1):40-5.

66. Duschner H, Götz H, White D, Kozak K, Zoladz J. Effects of hydrogen peroxide bleaching strips on tooth surface color, surface microhardness, surface and subsurface ultrastructure, and microchemical (Raman spectroscopic) composition. The Journal of clinical dentistry. 2006; 17(3):72-8.

67. Lewinstein I, Fuhrer N, Churaru N, Cardash H. Effect of different peroxide bleaching regimens and subsequent fluoridation on the hardness of human enamel and dentin. The Journal of prosthetic dentistry. 2004;92(4):337-42 .

68. Nizam BH, Lim C, Chng H, Yap A. Nanoindentation study of human premolars subjected to bleaching agent. Journal of biomechanics. 2005;38(11):2204-11.

69. Mondelli RFL, Gabriel TRCG, Rizzante FAP, Magalhães AC, Bombonatti JFS, Ishikiriama SK. Do different bleaching protocols affect the enamel microhardness? European journal of dentistry. 2015;9(1):25.

70. Parreiras S, Vianna P, Kossatz S, Loguercio A, Reis A. Effects of light activated in-office bleaching on permeability, microhardness, and mineral content of enamel. Operative dentistry. 2014;39(5):E225-E30.
71. Dionysopoulos D, Strakas D, Koliniotou-Koumpia E, Koumpia E. Effect of Er, Cr: YSGG laser irradiation on bovine enamel surface during in-office tooth bleaching ex vivo. Odontology. 2017;105(3):320-8.

72. Coceska E, Gjorgievska E, Coleman NJ, Gabric D, Slipper IJ, Stevanovic M, et al. Enamel alteration following tooth bleaching and remineralization. Journal of microscopy. 2016;262(3):232-44.

73. Furlan IS, Bridi EC, Amaral F, França F, Turssi CP, Basting RT. Effect of high-or low-concentration bleaching agents containing calcium and/or fluoride on enamel microhardness. Gen Dent. 2017;65(3):66-70.

74. Sasaki RT, Arcanjo AJ, Flório FM, Basting RT. Micromorphology and microhardness of enamel after treatment with home-use bleaching agents containing $10 \%$ carbamide peroxide and $7.5 \%$ hydrogen peroxide. Journal of Applied Oral Science. 2009;17(6):611-6.

75. Araujo Jr EM, Baratieri LN, Vieira LCC, Ritter AV. In situ effect of $10 \%$ carbamide peroxide on microhardness of human enamel: function of time. Journal of Esthetic and Restorative Dentistry. 2003;15(3):166-74.

76. Lopes GC, Bonissoni L, Baratieri LN, Vieira LCC, Monteiro Jr S. Effect of bleaching agents on the hardness and morphology of enamel. Journal of Esthetic and Restorative Dentistry. 2002;14(1):24-30.

77. Fatima N. In-vitro comparative study of in-office and home bleaching agents on surface micro-morphology of enamel. Journal of the College of Physicians and Surgeons Pakistan. 2016;26(1):9-12.

78. De Geus J, Wambier L, Boing T, Loguercio A, Reis A. At-home Bleaching With $10 \%$ vs More Concentrated Carbamide Peroxide Gels: A Systematic Review and Meta-analysis. Operative dentistry. 2018;43(4):E210-E22.

79. Leandro GAL, Attia ML, Cavalli V, do Rego MA, Liporoni PCS. Effects of $10 \%$ carbamide peroxide treatment and sodium fluoride therapies on human enamel surface microhardness. Group. 2008;330:320.

80. Costa JB, Mazur R. Effects of new formulas of bleaching gel and fluoride application on enamel microhardness: an in vitro study. Operative dentistry. 2007;32(6):589-94.

81. Pinto CF, Leme AFP, Cavalli V, Giannini M. Effect of $10 \%$ carbamide peroxide bleaching on sound and artificial enamel carious lesions. Brazilian dental journal. 2009;20(1):48-53. 
82. Cvikl B, Lussi A, Moritz A, Flury S. Enamel surface changes after exposure to bleaching gels containing carbamide peroxide or hydrogen peroxide. Operative dentistry. 2016;41(1):E39-E47.

83. Cordeiro D, Toda C, Hanan S, Arnhold L, Reis A, Loguercio A, et al. Clinical Evaluation of Different Delivery Methods of At-Home Bleaching Gels Composed of 10\% Hydrogen Peroxide. Operative dentistry. 2018.

84. Singh JKM, Sengut M, Halim MS, Ab-Ghani Z, Rahman NA. Safety comparison of over the counter bleaching with professionally prescribed home bleaching agent. European Journal of General Dentistry. 2018;7(2):35.

85. de Souza Paula S, Soares LES, do Espirito Santo AM, Martin AA, Cavalli V, Liporoni PCS. FT-Raman and energy dispersive X-ray fluorescence spectrometric analyses of enamel submitted to $38 \%$ hydrogen peroxide bleaching, an acidic beverage, and simulated brushing. Photomedicine and laser surgery. 2010;28(3):391-6.

86. Cavalli V, Rodrigues LKA, Paes-Leme AF, Brancalion ML, Arruda MAZ, Berger SB, et al. Effects of bleaching agents containing fluoride and calcium on human enamel. Quintessence International. 2010;41(8).

87. George L, Baby A, Dhanapal TP, Charlie K, Joseph A, Varghese AA. Evaluation and comparison of the microhardness of enamel after bleaching with fluoride free and fluoride containing carbamide peroxide bleaching agents and post bleaching anticay application: An in vitro study. Contemporary clinical dentistry. 2015;6(Suppl 1):S163. 